Images in...

\title{
Spontaneous Hickman line migration
}

\author{
Robert Loveridge, ${ }^{1}$ Stas Jankowski, ${ }^{2}$ Eoghan De Burca ${ }^{2}$ \\ ${ }^{1}$ Department of Anaesthesia, St. George's Hospital, London, UK; \\ 2Epsom \& St. Helier NHS Trust, Carshalton, UK
}

Correspondence to Robert Loveridge, robertloveridge@hotmail.com

\section{DESCRIPTION}

Spontaneous migration of subclavian Hickman lines is a recognised, albeit uncommon, complication of long-term central venous access (figure 1). ${ }^{1}{ }^{2}$ These images show the chest radiographs of a 56-year-old gentleman with mantle cell lymphoma and mediastinal lymphadenopathy immediately following placement in preparation for outpatient chemotherapy and then again at 1 month. Ideally, the catheter should lie with the superior vena cava to minimise the risk of complications and it should normally be seen at the level of the carina in adults on a chest radiograph.

They demonstrate that the catheter had migrated spontaneously into the ipsilateral internal jugular vein (figure 2). Risk factors for migration are thought to include catheter material characteristics, high intrathoracic pressures during physiotherapy and coughing and mediastinal lymphadenopathy. Once sited within the proximal internal jugular, the catheter is at a higher risk of a thrombosis and should

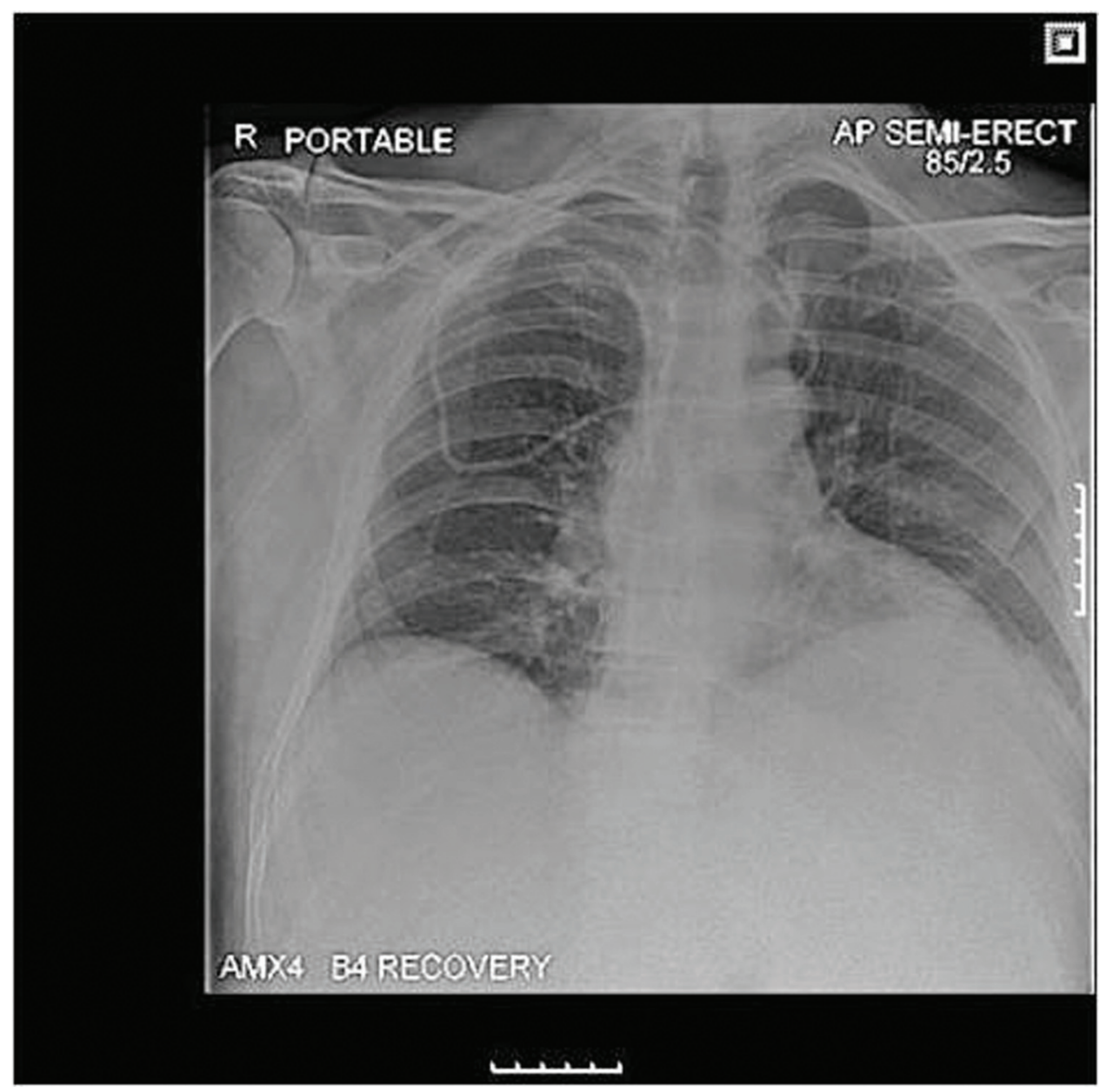

Figure 1 Right subclavian Hickman line immediately following placement. 


\section{BMJ Case Reports}

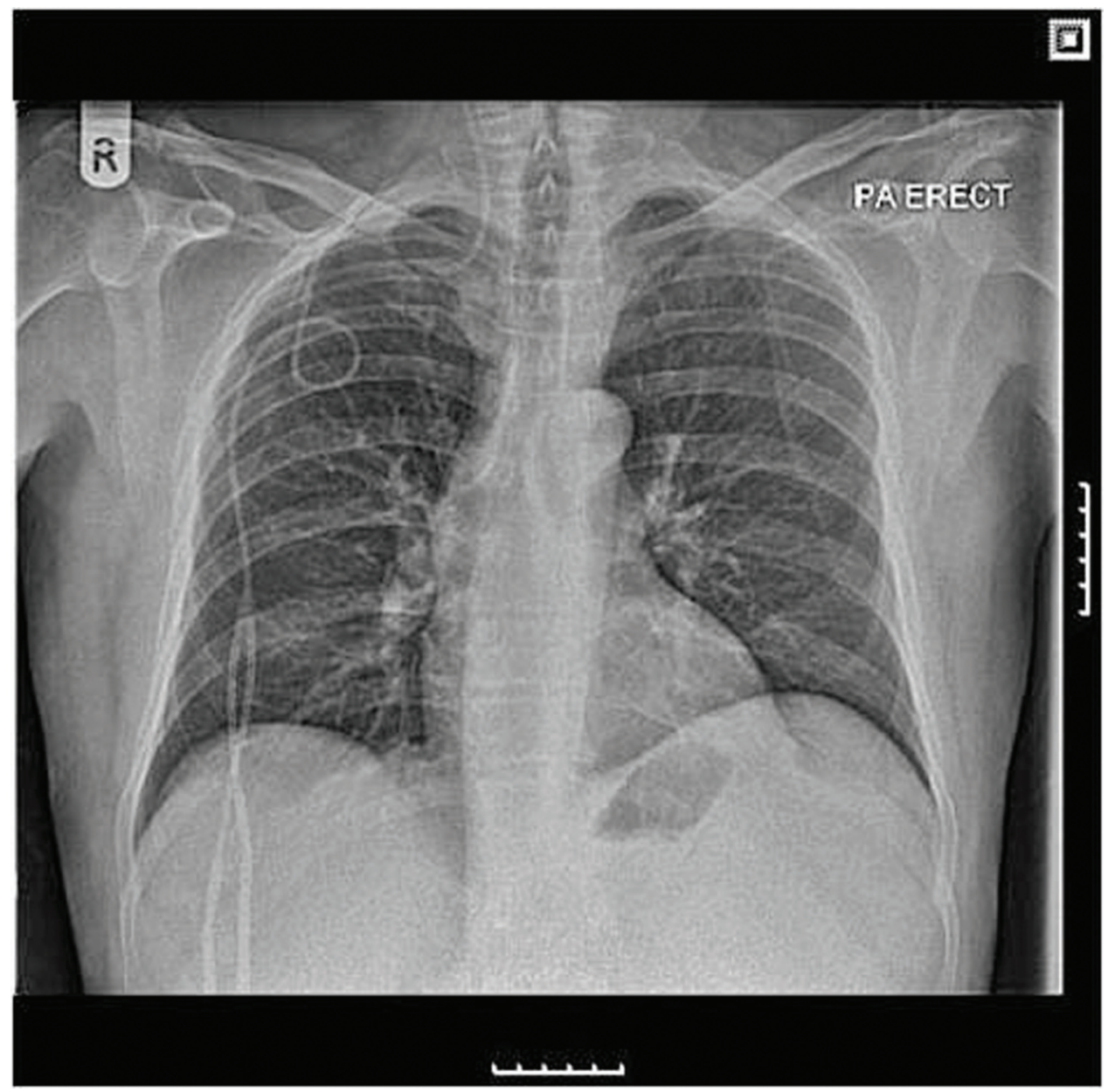

not be used for administration of chemotherapeutics just caudal to the jugular bulb.

Careful surveillance is recommended and the line was removed and re-sited without sequelae.

Competing interests None.

Patient consent Obtained

\section{REFERENCES}

1. Roblin D, Porter JC, Knight RK. Spontaneous migration of totally implanted venous catheter systems from subclavian into jugular veins. Thorax 1994; 49:281-2.

2. Collin GR, Ahmadinejad AS, Misse E. Spontaneous migration of subcutaneous central venous catheters. Am Surg 1997;63:322-6.

This pdf has been created automatically from the final edited text and images.

Copyright 2011 BMJ Publishing Group. All rights reserved. For permission to reuse any of this content visit http://group.bmj.com/group/rights-licensing/permissions.

BMJ Case Report Fellows may re-use this article for personal use and teaching without any further permission.

Please cite this article as follows (you will need to access the article online to obtain the date of publication)

Loveridge R, Jankowski S, Burca ED. Spontaneous Hickman line migration. BMJ Case Reports 2011;10.1136/bcr.02.2011.3916, date of publication

Become a Fellow of BMJ Case Reports today and you can:

- Submit as many cases as you like

- Enjoy fast sympathetic peer review and rapid publication of accepted articles

- Access all the published articles

- Re-use any of the published material for personal use and teaching without further permission

For information on Institutional Fellowships contact consortiasales@bmjgroup.com

Visit casereports.bmj.com for more articles like this and to become a Fellow 